\title{
Antimicrobial Activity of Cyclic-Monomeric and Dimeric Derivatives of the Snail-Derived Peptide Cm-p5 against Viral and Multidrug-Resistant Bacterial Strains
}

\author{
Melaine González-García ${ }^{1}$, Fidel Morales-Vicente ${ }^{2}$, Erbio Díaz Pico ${ }^{3}$, Hilda Garay ${ }^{3}$, Daniel G. Rivera ${ }^{4}$, \\ Mark Grieshober ${ }^{5}$, Lia Raluca Olari ${ }^{6}$, Rüdiger Groß ${ }^{6}{ }^{\mathbb{D}}$, Carina Conzelmann ${ }^{6}$, Franziska Krüger ${ }^{6}$, Fabian Zech ${ }^{6}$, \\ Caterina Prelli Bozzo ${ }^{6}$, Janis A. Müller ${ }^{6}$, Alexander Zelikin ${ }^{7}$, Heinz Raber ${ }^{8}$, Dennis Kubiczek ${ }^{8}$, \\ Frank Rosenau ${ }^{8}$ D, Jan Münch ${ }^{6,9}$ (D), Steffen Stenger ${ }^{5}$, Barbara Spellerberg ${ }^{5}$, Octavio L. Franco ${ }^{10, *(\mathbb{D})}$, \\ Armando A. Rodriguez Alfonso ${ }^{9}$ (D), Ludger Ständker ${ }^{9, *}$ (D) and Anselmo J. Otero-Gonzalez ${ }^{1, *}$
}

check for updates

Citation: González-García, M.; Morales-Vicente, F.; Pico, E.D.; Garay, H.; Rivera, D.G.; Grieshober, M.; Raluca Olari, L.; Groß, R.; Conzelmann, C.; Krüger, F.; et al. Antimicrobial Activity of Cyclic-Monomeric and Dimeric Derivatives of the Snail-Derived Peptide Cm-p5 against Viral and Multidrug-Resistant Bacterial Strains. Biomolecules 2021, 11, 745. https:// doi.org/10.3390/biom11050745

Academic Editor: Vladimir N. Uversky

Received: 10 November 2020

Accepted: 13 May 2021

Published: 17 May 2021

Publisher's Note: MDPI stays neutral with regard to jurisdictional claims in published maps and institutional affiliations.

Copyright: (c) 2021 by the authors. Licensee MDPI, Basel, Switzerland. This article is an open access article distributed under the terms and conditions of the Creative Commons Attribution (CC BY) license (https:/ / creativecommons.org/licenses/by/ $4.0 /)$.
1 Center for Protein Studies, Faculty of Biology, University of Havana, 25 St, La Habana 10400, Cuba; mgonzalez@fbio.uh.cu

2 General Chemistry Department, Faculty of Chemistry and Center for Natural Products Research, Faculty of Chemistry, University of Havana, Zapata street, La Habana 10400, Cuba; femvicente@gmail.com

3 Synthetic Peptides Group, Center for Genetic Engineering and Biotechnology, P.O. Box 6162, La Habana 10600, Cuba; erbio.diaz@cigb.edu.cu (E.D.P.); hilda.garay@cigb.edu.cu (H.G.)

4 Faculty of Chemistry, Havana University, Zapata Street, La Habana 10400, Cuba; dgr@fq.uh.cu

5 Institute of Medical Microbiology and Hygiene, University Clinic of Ulm, Albert-Einstein-Allee 23, 89081 Ulm, Germany; mark.grieshober@uniklinik-ulm.de (M.G.); Steffen.stenger@uniklinik-ulm.de (S.S.); barbara.spellerberg@uni-ulm.de (B.S.)

6 Institute of Molecular Virology, University Clinic of Ulm, Meyerhofstrasse. 1, 89081 Ulm, Germany; lia-raluca.olari@uni-ulm.de (L.R.O.); ruediger.gross@uni-ulm.de (R.G.); carina.conzelmann@uni-ulm.de (C.C.); franziska.krueger@uni-ulm.de (F.K.); fabian.zech@uni-ulm.de (F.Z.); caterina.prelli-bozzo@uni-ulm.de (C.P.B.); janis.mueller@uni-ulm.de (J.A.M.); jan.muench@uni-ulm.de (J.M.)

7 Department of Chemistry, Aarhus University, Langelandsgade 140, 8000 Aarhus, Denmark; zelikin@chem.au.dk

8 Institute of Pharmaceutical Biotechnology, Ulm University, 89081 Ulm, Germany; Heinz.Raber@uni-ulm.de (H.R.); dennis.kubiczek@uni-ulm.de (D.K.); frank.rosenau@uni-ulm.de (F.R.)

9 Core Facility for Functional Peptidomics, Ulm Peptide Pharmaceuticals (U-PEP), Faculty of Medicine, Ulm University, 89081 Ulm, Germany; armando.rodriguez-alfonso@uni-ulm.de

10 Department of Biotechnology, Catholic University Dom Bosco, Campo Grande and Center for Biochemical and Proteomics Analyses, Catholic University of Brasilia, Brasilia, DF 71966-700, Brazil

* Correspondence: ocfranco@gmail.com (O.L.F.); ludger.staendker@uni-ulm.de (L.S.); aotero@fbio.uh.cu (A.J.O.-G.)

Abstract: Cm-p5 is a snail-derived antimicrobial peptide, which demonstrated antifungal activity against the pathogenic strains of Candida albicans. Previously we synthetized a cyclic monomer as well as a parallel and an antiparallel dimer of $\mathrm{Cm}$-p5 with improved antifungal activity. Considering the alarming increase of microbial resistance to conventional antibiotics, here we evaluated the antimicrobial activity of these derivatives against multiresistant and problematic bacteria and against important viral agents. The three peptides showed a moderate activity against Pseudomonas aeruginosa, Klebsiella pneumoniae Extended Spectrum $\beta$-Lactamase (ESBL), and Streptococcus agalactiae, with MIC values $>100 \mu \mathrm{g} / \mathrm{mL}$. They exerted a considerable activity with MIC values between $25-50 \mu \mathrm{g} / \mathrm{mL}$ against Acinetobacter baumanii and Enterococcus faecium. In addition, the two dimers showed a moderate activity against Pseudomonas aeruginosa PA14. The three Cm-p5 derivatives inhibited a virulent extracellular strain of Mycobacterium tuberculosis, in a dose-dependent manner. Moreover, they inhibited Herpes Simplex Virus 2 (HSV-2) infection in a concentration-dependent manner, but had no effect on infection by the Zika Virus (ZIKV) or pseudoparticles of Severe Acute Respiratory Syndrome Corona Virus 2 (SARS-CoV-2). At concentrations of $>100 \mu \mathrm{g} / \mathrm{mL}$, the three new Cm-p5 derivatives showed toxicity on different eukaryotic cells tested. Considering a certain cell toxicity but a potential interesting activity against the multiresistant strains of bacteria and HSV-2, our compounds require future structural optimization. 
Keywords: antimicrobial peptides; Cm-p5; antibacterial activity; multiresistant microorganisms; chemical derivatives

\section{Introduction}

Cm-p5 is an antimicrobial peptide composed of 12 amino acid residues (SRSELIVHQRLF-NH ${ }_{2}$, PDB ID: 2MP9, BMRB access number: 19973) with an $\alpha$-helical structure in membrane-mimetic conditions and a tendency to a random structure in aqueous solutions. This peptide was synthesized using $\mathrm{Cm}-\mathrm{p} 1$ as a template, in order to improve its antifungal activity. $\mathrm{Cm}-\mathrm{p} 1$ is a cationic peptide of 10 amino acid residues (SRSELIVHQR) derived from the marine snail Cenchritis muricatus, Linnaeus, 1758 (Gastropoda: Littorinidae). In previous studies, $\mathrm{Cm}$-p5 showed antifungal activity against the pathogenic yeast species Candida albicans and Candida parapsilosis and did not exhibit hemolytic activity or any toxic effect against mammalian cell lines in vitro [1,2].

Despite its potential clinical benefits, $\mathrm{Cm}$-p5 might not be a suitable therapeutic agent, due to its proteolytic instability and lower activity, as compared to conventional antifungals. We therefore synthesized a cyclic monomer and two dimers (parallel and antiparallel) of $\mathrm{Cm}$-p5 through the introduction of disulfide bonds (Figure 1). These novel derivatives revealed a helical stabilization with improved antifungal activity for the cyclic monomer and an unexpected antibacterial activity against Pseudomonas aeruginosa and Listeria monocytogenes for the antiparallel dimer. In addition, neither the cyclic monomer nor the dimers were toxic. The antimicrobial activity, the low cytotoxicity, and the stabilization of the $\alpha$-helix of these derivatives, suggest a greater metabolic stability and activity in vivo [3].<smiles>NCCCCCCCCCCCCC(=O)O</smiles>

SRS、<smiles>N[R17]OC(=O)[C@H]1CSSC[C@@H](NS)C(=O)[AlH]N1</smiles>

Cyclic Cm-p5
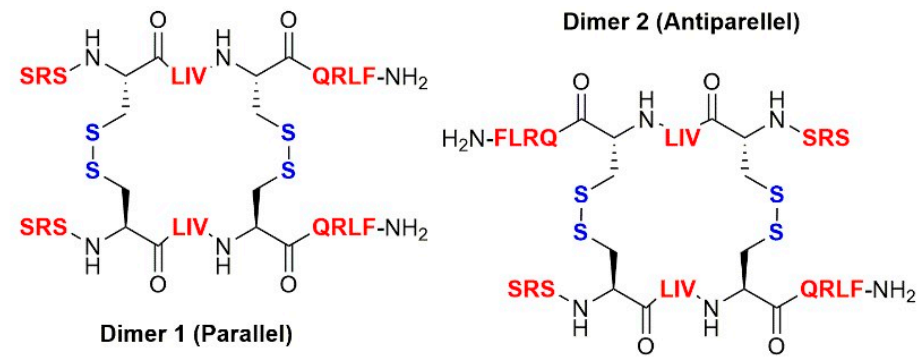

Figure 1. Structure of the designed cyclic analogues of Cm-p5.

The emergence of multiresistant pathogens is one of the greatest threats to humanity. It represents a tremendous challenge for public health in the near future, and there is an urgent need for alternative antimicrobial substances [4]. In this context, antimicrobial peptides (AMPs), represent promising candidates for the treatment of infectious diseases [5]. The therapeutic potential of AMPs is mainly because they have a broad spectrum of activity against various microorganisms (fungi, bacteria, viruses, and parasites), exert potential in vitro activity against multiresistant strains, and are generally slightly toxic to host cells [6]. Moreover, development of resistance against AMP is unlikely to occur [7]. Additionally, they have a wide distribution in nature and serve an important function as effectors of innate immunity in invertebrates [8], so not only can they act directly on microorganisms but also indirectly through the innate immune system activation [9].

There are many sources of AMPs according to the Antimicrobial Peptide Database (https:/ / wangapd3.com/main.php) but chemical or biotechnological derivatives are reported as a practical and effective source of modified peptides with increased antimicrobial activity or decreased in vitro cytotoxicity [10].

In this work, we enlarge the bacterial and viral spectrum in order to explore the antimicrobial activity of $\mathrm{Cm}-\mathrm{p} 5$ and its derivatives against viral and multiresistant or problematic bacterial strains. 


\section{Materials and Methods}

\subsection{Bacterial Strains and Growth Conditions}

We used the following bacterial species: Streptococcus agalactiae ATCC 12403, Staphylococcus aureus MRSA ATCC 43300, Klebsiella pneumoniae Extended Spectrum $\beta$-Lactamase (ESBL) ATCC 700603, Acinetobacter baumanii ATCC19606, and Enterococcus faecium (VRE) DSM17050. Bacteria were cultured at $37^{\circ} \mathrm{C} / 5 \% \mathrm{CO}_{2}$ in liquid THY broth (Todd-Hewitt Broth, Oxoid, Hampshire, UK) supplemented with $0.5 \%$ yeast extract (BD, Miami, FA, USA). Pseudomonas aeruginosa PA14 (DSM 19882) was cultivated in liquid Müller-Hinton-Broth (Carl Roth, Karlsruhe, Germany) at $37^{\circ} \mathrm{C}$, under orbital shaking at $160 \mathrm{rpm}$.

In addition, the employed Mycobacterium tuberculosis ATCC $27294(\mathrm{Mtb})$ was grown in 7H9-medium containing 7H9 BBL Middlebrook broth (BD), glycerol (Honeywell, Charlotte, NC, USA) OADC (Oelic Albumin Dextrose Catalase; BD), Tween 80 (Roth, Karlsruhe, Germany), and $\mathrm{ddH}_{2} \mathrm{O}$. The $\mathrm{pH}$ was adjusted between 7.2-7.4 and sterile filtration was performed with a $0.2-\mu \mathrm{m}$ filter membrane (Thermo Scientific ${ }^{\mathrm{TM}}$ Nalgene $^{\mathrm{TM}}$ Rapid-Flow $^{\mathrm{TM}}$, Thermo Scientific, Bremen, Germany).

\subsection{Mammalian Cell Lines and Culture Conditions}

Vero E6 (Cercopithecus aethiops derived epithelial kidney) cells were grown in Dulbecc's modified Eagle's medium (DMEM) supplemented with 2.5\% heat-inactivated fetal calf serum (FCS), $2 \mathrm{mM} \mathrm{L-glutamine,} 100$ units $/ \mathrm{mL}$ penicillin, $100 \mu \mathrm{g} / \mathrm{mL}$ streptomycin, $1 \mathrm{mM}$ sodium pyruvate, and non-essential amino acids (Sigma \#M7145, St. Louis, MI, USA). HEK293T cells are a human cell line originally derived from embryonic kidney. Transformed by adenovirus type 5 expressing SV40 (simian virus 40) large T-antigen [11]. ELVIS $^{\text {TM }}$ (Enzyme-Linked Virus-Inducible System) are a baby hamster kidney cell line encoding lacZ gene, which is expressed upon infection via viral transactivator ICP10 [12].

HEK293T and ELVIS ${ }^{\mathrm{TM}}$ cells were cultured in DMEM supplemented with $2 \mathrm{mM} \mathrm{L-}$ glutamine, 100 units $/ \mathrm{mL}$ penicillin, and $100 \mu \mathrm{g} / \mathrm{mL}$ streptomycin, and $10 \%$ heat-inactivated FCS. Caco-2 (human epithelial colorectal adenocarcinoma) cells were grown in DMEM supplemented with $20 \% \mathrm{FCS}, 100$ units / $\mathrm{mL}$ penicillin, $100 \mu \mathrm{g} / \mathrm{mL}$ streptomycin, $1 \mathrm{mM}$ sodium pyruvate, and non-essential amino acids (Sigma Aldrich, St. Louis, MO, USA) and seeded in the same medium with only $10 \%$ FCS for experiments. Cells were grown at $37^{\circ} \mathrm{C}$ in a $5 \% \mathrm{CO}_{2}$ humidified incubator.

\subsection{Peptide Synthesis}

Solid phase peptide synthesis was based on the use of Fmoc/t-Bu chemistry on rink amide resin, based on polystyrene or PEG (Sigma Aldrich). The resin was washed with DMF $(2 \times 2 \mathrm{~mL}, 1 \mathrm{~min}), \mathrm{DCM}(2 \times 2 \mathrm{~mL}, 1 \mathrm{~min}), \mathrm{MeOH}(2 \times 2 \mathrm{~mL}, 1 \mathrm{~min}), \mathrm{DCM}(2 \times 2 \mathrm{~mL}$, $1 \mathrm{~min})$, and DMF $(2 \times 2 \mathrm{~mL}, 1 \mathrm{~min})$. Fmoc removal was conducted with $20 \%$ piperidine in DMF $(2 \times 10 \mathrm{~min})$, and the subsequent amino acids were added using the coupling condition-Fmoc-Aa-OH/DIC/Oxyma (4 equivalent of each) in DMF, after a negative ninhydrin test (approximately $30 \mathrm{~min}$ ). All peptides were prepared with more than $95 \%$ purity as evaluated by analytical RP-HPLC. The molecular mass was experimentally established by ESI-MS, in correspondence with the theoretically calculated monoisotopic mass for each peptide vivo [3].

\subsection{Antibacterial Activity}

\subsubsection{Agar Overlay Assay}

Bacteria were cultured at $37^{\circ} \mathrm{C} / 5 \% \mathrm{CO}_{2}$ overnight, pelleted by centrifugation and washed in $10 \mathrm{mM}$ sodium phosphate buffer. Following resuspension in $10 \mathrm{mM}$ sodium phosphate buffer, optical density was determined at $600 \mathrm{~nm} .2 \times 10^{7}$ bacteria were seeded into a petri dish in $1 \%$ agarose and $10 \mathrm{mM}$ sodium phosphate buffer. After cooling at $4{ }^{\circ} \mathrm{C}$ for $30 \mathrm{~min}, 3-5 \mathrm{~mm}$ holes were cut into the $1 \%$ agarose. Peptides adjusted to the desired concentration in $10 \mu \mathrm{L}$ of buffer were filled into the agar-holes. Following an incubation at $37^{\circ} \mathrm{C}$ in ambient air for $3 \mathrm{~h}$, the plates were overlaid with $1 \%$ agarose and $3 \%$ tryptic 
soy solved in $10 \mathrm{mM}$ phosphate buffer. Inhibition zones in millimeter were determined following a $16-18 \mathrm{~h}$ incubation time at $37^{\circ} \mathrm{C} / 5 \% \mathrm{CO}_{2}$.

\subsubsection{Minimal Inhibitory Concentration (MIC) Determinations}

MIC evaluations were performed in Mueller-Hinton broth in accordance with CLSI guidelines, following overnight incubation at $37{ }^{\circ} \mathrm{C}$. All tests were performed in triplicates [13].

\subsection{H-Uracil Proliferation Assay}

Extracellular bacteria $\left(2 \times 10^{6}\right.$ cells $\left./ \mathrm{mL}\right)$ were distributed into 96 -well flat bottom plates (Nunc; ThermoFisher, Bremen, Germany) in triplicates and incubated for 3 days at $37^{\circ} \mathrm{C} / 5 \% \mathrm{CO}_{2}$. Next, ${ }^{3} \mathrm{H}$-Uracil $(0.3 \mu \mathrm{Ci} / \mathrm{mL}$, Biotrend, Köln, Germany) was added overnight at $37{ }^{\circ} \mathrm{C} / 5 \% \mathrm{CO}_{2}$. Mtb were then fixed and killed with $4 \%$ paraformaldehyde (PFA) at room temperature (RT) for $20 \mathrm{~min}$, and were then harvested (Cell harvester; Inotech, Derwood, MD, USA) onto a filtermat (Perkin Elmer, Waltham, MA, USA). Afterwards, wax plates (Meltilex A; Perkin Elmer) containing scintillation liquid were molten onto the mats. Samples were measured with a beta counter (Hidex sense micro beta counter; Turku, Finland) and the mean values of the triplicates were calculated.

\subsection{Effect of Peptides on Zika Virus Infection}

Virus stocks of ZIKV MR766, a ZIKV strain isolated from a sentinel rhesus macaque in 1947 [14] were generated by inoculating 70\% confluent Vero E6 cells in $175 \mathrm{~cm}^{2}$ cell culture flasks for $2 \mathrm{~h}$, before adding a $40 \mathrm{~mL}$ medium. After 3-5 days, the virus was collected by centrifuging the cell supernatant to remove cell debris for $3 \mathrm{~min}$ at $330 \times \mathrm{g}$. Virus stocks were stored at $-80^{\circ} \mathrm{C}$. To determine the ZIKV infection, 6,000 Vero E6 cells were seeded into 96-well plates the day before. Peptides were dissolved in 3\% DMSO and centrifuged for $10 \mathrm{~min}$ at $14,000 \times \mathrm{g}$. ZIKV was mixed $1: 1$ with $0,33.3,100$, and $300 \mu \mathrm{g} / \mathrm{mL}$ of the peptides or PSVBS, and 3\% DMSO [15] as controls, and incubated for $2 \mathrm{~h}$ at $37^{\circ} \mathrm{C}$, before adding $20 \mu \mathrm{L}$ of the mixture on cells. Two days later, infection rates were determined with a cell-based ZIKV immunodetection assay [16,17]. Cells were washed with Phosphate Buffer Saline (PBS) and fixed with $4 \%$ paraformaldehyde (PFA) for $20 \mathrm{~min}$ at room temperature. Cell permeabilization was performed with cold methanol for $5 \mathrm{~min}$ at $4{ }^{\circ} \mathrm{C}$ and the cells were then washed with PBS. Afterwards, the cells were incubated with mouse anti-flavivirus antibodies $4 \mathrm{G} 2$ in antibody buffer, for $1 \mathrm{~h}$ at $37^{\circ} \mathrm{C}$, washed 3 times with washing buffer, and incubated with an HRP-coupled anti-mouse antibody $(1: 20,000)$ for $1 \mathrm{~h}$ at $37^{\circ} \mathrm{C}$. After 4 washing steps with PBS, the TMB substrate was added. After an incubation of $5 \mathrm{~min}$ at room temperature, the reaction was stopped with $0.5 \mathrm{M}$ sulfuric acid, and absorption was measured at $450 \mathrm{~nm}$, and the baseline was corrected at $650 \mathrm{~nm}$, using an ELISA microplate reader (Molecular Devices, Silicon Valley, CA, USA). Values were corrected for the background signal derived from the uninfected cells and the untreated controls were set to $100 \%$ infection.

\subsection{Effect of Peptides on HSV Infection}

The Herpes-Simplex-Virus 2 (Strain 333) was kindly provided by Patricia Spear (Northwestern University, Evanston, IL, USA). The virus was propagated as described for ZIKV. Supernatants were centrifuged for $3 \mathrm{~min}$ at $330 \times g$, to remove cellular debris, and then aliquoted and stored at $-80^{\circ} \mathrm{C}$ as virus stocks. To determine the HSV-2 infection, 5000 ELVIS cells were seeded the day before into 96-well-flat-bottom plates. Before infection, the cell medium was removed and $80 \mu \mathrm{L}$ of X-vivo cell medium supplemented with $2 \mathrm{mM}$ L-glutamine, 100 units $/ \mathrm{mL}$ penicillin, and $100 \mu \mathrm{g} / \mathrm{mL}$ streptomycin was added. Peptides were dissolved in $3 \%$ DMSO and centrifuged for 10 min at $14,000 \times g$. Experiments were done by mixing $35 \mu \mathrm{L}$ of the peptide samples in concentrations of $0,33.3,100$, and $300 \mu \mathrm{g} / \mathrm{mL}$ of the peptides or PSVBS, and 3\% DMSO as controls, with $35 \mu \mathrm{L}$ of HSV-2 for $2 \mathrm{~h}$ at $37^{\circ} \mathrm{C}$. Then, $20 \mu \mathrm{L}$ of the peptide-virus mix were added to each well. One day post- 
infection, the medium was discarded and $40 \mu \mathrm{L}$ of diluted Gal-Screen ${ }^{\circledR}$ substrate/buffer A (1:4 in PBS) (ThermoFisher Scientific, Waltham, MA, USA) was added for 30 min of room temperature incubation. Then, $35 \mu \mathrm{L}$ were transferred into white 96 -well plates and the substrate conversion was measured as relative light units per second, using the Orion II Microplate Luminometer. Values were corrected for the background signal derived from the uninfected cells.

\subsection{Effect of Peptides on SARS-CoV-2 Pseudo Particles \\ 2.8.1. Pseudotyping of VSV with SARS-CoV-2S}

Viral pseudoparticles based on the vesicular stomatitis virus containing the Spike protein of SARS-CoV-2 were produced, as previously described, with minor modifications [18]. HEK293T cells were first transfected with pCG1-SARS-2-S (kindly provided by Stefan Poehlmann, German Primate Center, Göttingen, Germany), using Transit LT-1 (Mirus, \#MIR2306) and one day later, transduced by replication-deficient $V_{S V}^{*} \Delta G$ Gluc_eGFP pseudotyped with VSV-G (kindly provided by Gert Zimmer, Institute of Virology and Immunology, Mittelhäusern, Switzerland) [19]. After $1 \mathrm{~h}$ of incubation, the inoculum was removed, cells were washed $3 \times$ with PBS, and a fresh medium was added. After $16 \mathrm{~h}$, supernatants were harvested and centrifuged to pellet cellular debris. The supernatant from hybridoma cells expressing anti-VSV-G antibodies (I1, mouse hybridoma supernatant from CRL-2700; ATCC) was added to the clarified pseudoparticle stocks at 1:10 (v/v) ratio, to block residual VSV-G-containing particles, before concentrating the supernatants 10-fold by volume, using the $100 \mathrm{kDa}$ MWCO Amicon Ultrafiltration columns (Sigma-Aldrich, \# UFC910096, St. Louis, MO, USA), aliquoting and storing at $-80^{\circ} \mathrm{C}$ until use.

\subsubsection{Transduction Experiments with SARS-CoV-2 Spike-Pseudoparticles}

Transduction experiments with pseudoparticles were performed on Caco-2 cells. In brief, 10,000 Caco-2 cells were seeded onto the 96-well-flat-bottom plates, one day prior. Peptides were incubated with pseudoparticles at the indicated concentrations for $1 \mathrm{~h}$ at $37^{\circ} \mathrm{C}$, before adding the mixtures to cells at 1:10 dilution. Sixteen hours post-transduction, the medium was removed and the cells were washed once with PBS, before adding the Luciferase Cell Culture Lysis Reagent (Promega \#E1531, Madison, WI, USA). The lysates were then transferred to white 96-well plates, $50 \mu \mathrm{L}$ Luciferase Assay System Reagent (Promega \#E1500, Madison, WI, USA) was added and substrate conversion was measured as relative light units per second, using the Orion II Microplate Luminometer. The values were corrected for the background signal derived from the untransduced cells.

\subsubsection{Cell Viability Assay}

Vero and ELVIS cells were seeded, as described above in the infection experiments. The next day, peptides were added at the indicated concentration and cell viability was quantified after $48 \mathrm{~h}$, with the MTT (3-(4,5-dimethylthiazole-2-yl)-2,5-diphenyl tetrazolium bromide,)-based assay. In brief, the medium was removed and $90 \mu \mathrm{L}$ PBS and $10 \mu \mathrm{L}$ MTT (5 mg/mL in PBS, Sigma-Aldrich, St. Louis, MO, USA) solution were added per well. Following a $2.5 \mathrm{~h}$ incubation time at $37^{\circ} \mathrm{C}$, the supernatant was discarded and the formazan crystals were dissolved in $100 \mu \mathrm{L}$ 1:1 DMSO-EtOH solution. Absorption was measured at $450 \mathrm{~nm}$ and the baseline was corrected at $650 \mathrm{~nm}$, using a Vmax kinetic microplate reader (Molecular Devices, Silicon Valley, CA, USA). The untreated controls were set to $100 \%$ viability. For cytotoxicity evaluation on Caco-2 cells, CellTiter-Glo ${ }^{\circledR}$ Luminescent Cell Viability Assay (Promega \#G7571, Madison, WI, USA) was used as instructed by the manufacturer, with minor modifications. The medium was removed from cells, CellTiterGlo reagent (diluted 1:1 with PBS) was added and incubated for $10 \mathrm{~min}$ at RT before transferring the lysates to white 96 -well plates and measuring the luminescence as relative light units per second, using the Orion II Microplate Luminometer. The untreated controls were set to $100 \%$ viability. 


\section{Results}

For more comprehensive antimicrobial examinations, the three $\mathrm{Cm}-\mathrm{p} 5$ peptides were chemically resynthesized in large scale amounts (>100 $\mathrm{mg}$ batches) and were properly folded and analyzed, as described previously [3].

\subsection{Antibacterial Activity}

The antibacterial activity of the antimicrobial peptide Cm-p5, the cyclic- monomer and the two associated dimers (Figure 1) against Streptococcus agalactiae, Staphylococcus aureus MRSA, Klebsiella pneumoniae ESBL, Acinetobacter baumanii, and Enterococcus faecium (VRE) in the Agar overlay assay is shown in Table 1. As expected and demonstrated before [3] (results not shown), unmodified Cm-p5 was unable to exert antibacterial activity. On the other hand, the monomer and two dimers showed activity against K. pneumoniae ESBL, Acinetobacter baumanii, and Enterococcus faecium (VRE). While the peptides showed activity against K. pneumoniae ESBL only at 100 and $1000 \mu \mathrm{g} / \mathrm{mL}$, A. baumanii and E. faecium were sensitive to all concentrations of the derivatives that we tested. However, only the cyclic monomer was able to inhibit $S$. aureus MRSA.

Table 1. Agar diffusion test of Gram-positive and Gram-negative bacterial species against the antimicrobial peptides CMP5 cys-cys monomer and dimer 1 and dimer 2 .

\begin{tabular}{|c|c|c|c|c|c|c|c|c|c|c|}
\hline \multirow[b]{2}{*}{ Bacterial Species } & \multicolumn{3}{|c|}{ CMP5 cys-cys Monomer } & \multicolumn{3}{|c|}{ CMP5 cys-cys Dimer1 } & \multicolumn{3}{|c|}{ CMP5 cys-cys Dimer2 } & \multirow{2}{*}{$\begin{array}{c}\text { LL-37 } \\
\begin{array}{c}1 \\
\mathrm{mg} / \mathrm{L}\end{array}\end{array}$} \\
\hline & $\begin{array}{l}1000 \\
\mathrm{mg} / \mathrm{L}\end{array}$ & $\begin{array}{c}100 \\
\mathrm{mg} / \mathrm{L}\end{array}$ & $\begin{array}{c}20 \\
\mathrm{mg} / \mathrm{L}\end{array}$ & $\begin{array}{l}1000 \\
\mathrm{mg} / \mathrm{L}\end{array}$ & $\begin{array}{c}100 \\
\mathrm{mg} / \mathrm{L}\end{array}$ & $\begin{array}{c}20 \\
\mathrm{mg} / \mathrm{L}\end{array}$ & $\begin{array}{l}1000 \\
\mathrm{mg} / \mathrm{L}\end{array}$ & $\begin{array}{c}100 \\
\mathrm{mg} / \mathrm{L}\end{array}$ & $\begin{array}{c}20 \\
\mathrm{mg} / \mathrm{L}\end{array}$ & \\
\hline $\begin{array}{l}\text { Streptococcus } \\
\text { agalactiae }\end{array}$ & 0.8 & 0.4 & - & 1 & 0.7 & - & 1.1 & 0.6 & 0.3 & n.d. \\
\hline $\begin{array}{c}\text { Staphylococcus aureus } \\
\text { MRSA }\end{array}$ & - & - & - & - & - & - & - & - & - & 0.1 \\
\hline Listeria monocytogenes & 0.9 & 0.5 & - & 1.2 & 0.7 & 0.3 & 1.2 & 0.8 & 0.3 & 1.1 \\
\hline $\begin{array}{c}\text { Klebsiella pneumoniae } \\
\text { ESBL }\end{array}$ & 0.6 & - & - & 0.7 & 0.5 & - & 0.9 & 0.5 & - & 0.8 \\
\hline $\begin{array}{l}\text { Pseudomonas } \\
\text { aeruginosa }\end{array}$ & 0.8 & 0.4 & - & 1 & 0.7 & 0.3 & 1 & 0.6 & 0.3 & 0.8 \\
\hline $\begin{array}{c}\text { Acinetobacter baumanii } \\
\text { ATCC } 19606\end{array}$ & 0.7 & 0.4 & - & 1 & 0.6 & 0.4 & 0.9 & 0.6 & 0.4 & 0.7 \\
\hline $\begin{array}{l}\text { Enterococcus faecium } \\
\text { VRE DSM } 17050\end{array}$ & 0.9 & 0.6 & 0.4 & 1.1 & 0.8 & 0.5 & 1.1 & 0.8 & 0.5 & 1.0 \\
\hline
\end{tabular}

Susceptibility against different concentrations of the three AMPs was tested by agar diffusion assay. A total of $10 \mu \mathrm{L}$ of a stock solution at a concentration as indicated above was spotted on to an agar containing the respective bacterial species. After overnight incubation at $37^{\circ} \mathrm{C}$, inhibition zones around the tested AMP were measured in centimeters. Determinations were done in triplicates. LL-37 was used as a positive control. n.d.: not determined.

Next, we determined the antibacterial MIC of Cm-p5 derivatives against the Grampositive strain S. agalactiae and the Gram-negative species K. pneumoniae ESBL and P. aeruginosa PA14. In this experiment, none of the $\mathrm{Cm}$-p5 derivatives exhibited a significantly antibacterial activity against K. pneumoniae ESBL and S. agalactiae. However, dimer 2 was moderately active against $P$. aeruginosa PA14, with an MIC of $141.3 \mu \mathrm{g} / \mathrm{mL}$.

\subsection{Antimycobacterial Activity}

The antimycobacterial activity of $\mathrm{Cm}$-p 5 derivatives on virulent extracellular Mtb is shown in Figure 2. All derivatives exhibited antimycobacterial activity in a concentrationdependent manner. Nevertheless, Dimer 2 (antiparallel) showed the highest activity among the derivatives with $50 \%$ antimycobacterial activity at $30 \mu \mathrm{g} / \mathrm{mL}$. 

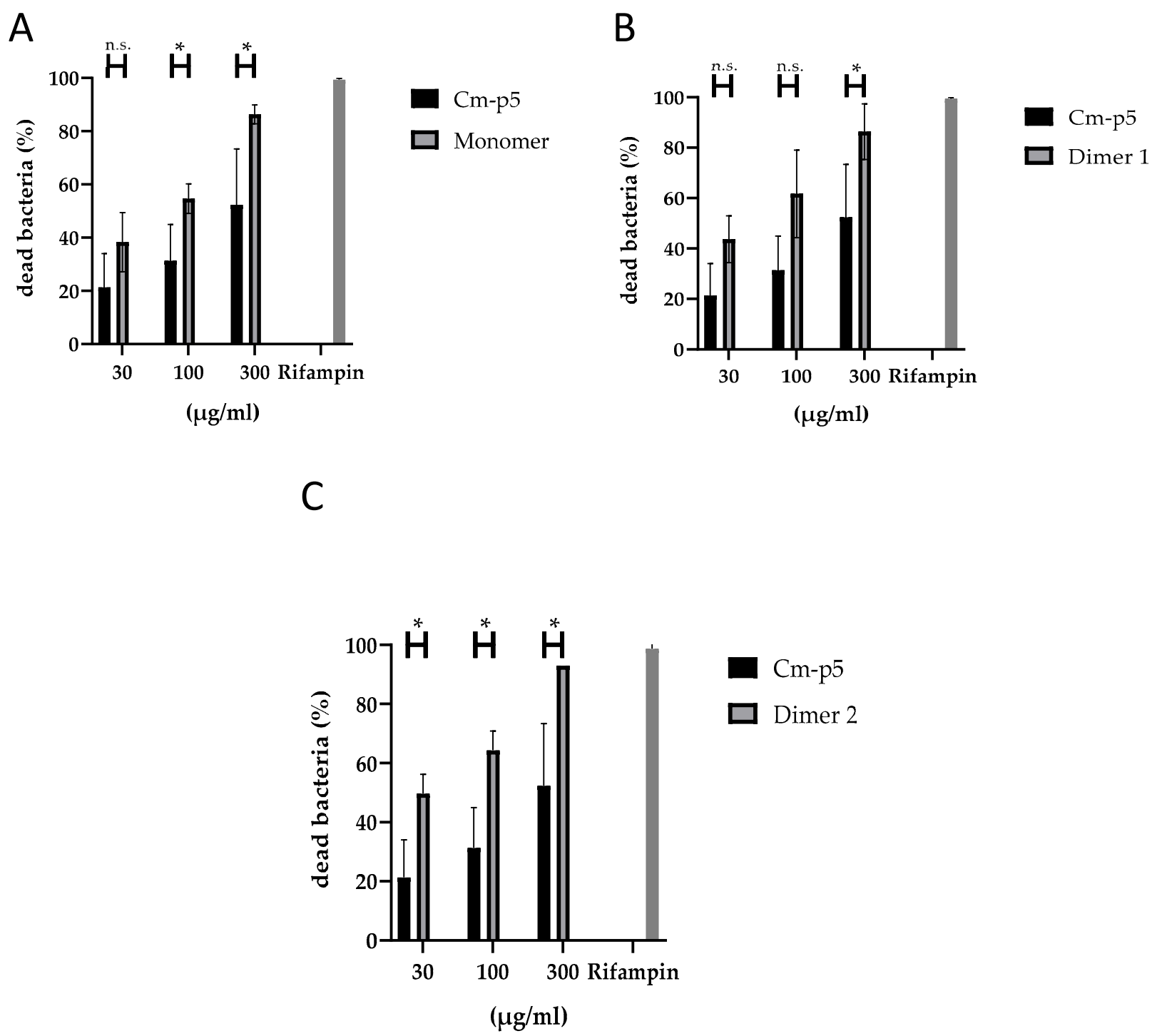

Figure 2. Antimycobacterial activity of Cm-p5 and its derivatives Monomer, cyclic (A), Dimer 1 (B) and Dimer 2 (C) at different concentrations ( $30 \mu \mathrm{g} / \mathrm{mL}, 100 \mu \mathrm{g} / \mathrm{mL}, 300 \mu \mathrm{g} / \mathrm{mL}$ ) on virulent extracellular Mycobacterium tuberculosis was determined using ${ }^{3} \mathrm{H}$-uracil proliferation assay. Bacteria were incubated in the presence of AMPs for 3 days and an additional day with ${ }^{3} \mathrm{H}$-Uracil. Rifampin $(2 \mu \mathrm{g} / \mathrm{mL})$ was used as a positive control. Experiments were performed in triplicates and the results are shown as mean values of three independent experiments. Statistical significance was calculated using the Wilcoxon rank-sum test (n.s. $=$ not significant, ${ }^{*}=p \leq 0.05$ ).

\subsection{Antiviral Activity}

First, we determined a possible antiviral effect of the peptides against viral pseudoparticles (PP) that carry the spike protein of the pandemic SARS-CoV-2. For this, luciferase-encoding SARS-CoV-2 Spike PP were treated with peptides at concentration up to $300 \mu \mathrm{g} / \mathrm{mL}$, and then the Caco2 cells permissive for SARS-CoV-2 were inoculated. Infection rates were determined $18 \mathrm{~h}$ later, by quantifying the luciferase activities in cellular lysates. As shown in Figure 3A, none of the peptides suppressed SARS-CoV-2 Spike PP infection. In contrast, the SARS-CoV-2 entry inhibitor EK1, a peptide that prevents the formation of the 6-helix-bundle in the Spike protein [20,21], suppressed SARS-CoV-2 PP infection in a concentration-dependent manner (Figure 3B), whereas DMSO showed no effect on infection (Figure 3C). At concentrations $>300 \mu \mathrm{g} / \mathrm{mL}$, the three Cm-p5 derivatives showed some cytotoxicity to the $\mathrm{Caco} 2$ cells (Figure 3D), the reference inhibitor EK-1 showed some toxicity at the highest concentration tested ( $50 \mu \mathrm{M}$; Figure $3 \mathrm{E})$ but DMSO did not show any toxicity in the concentrations used (Figure 3F). 
A

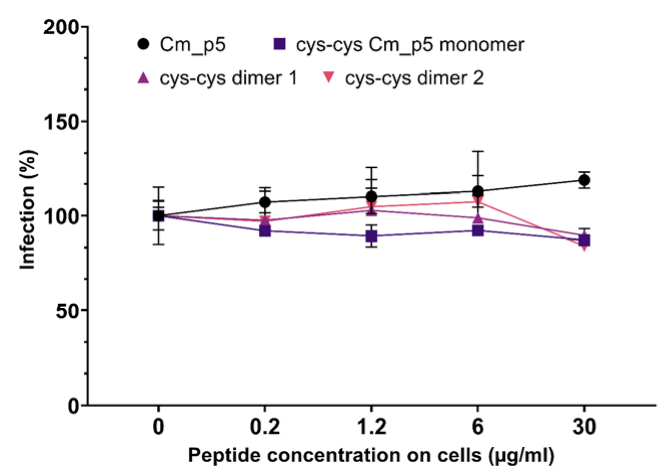

D

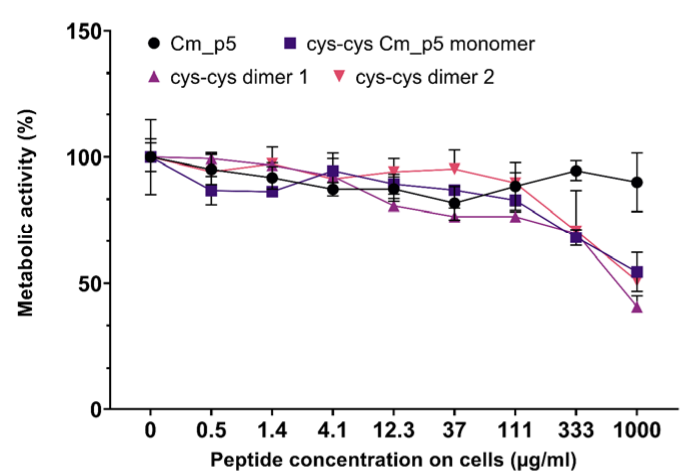

B

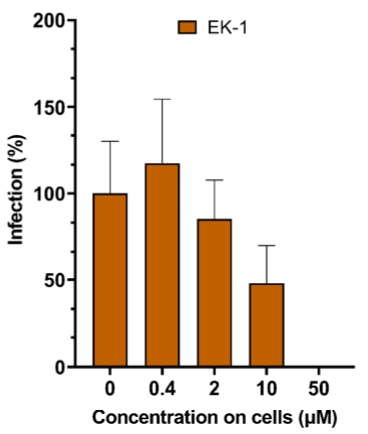

E

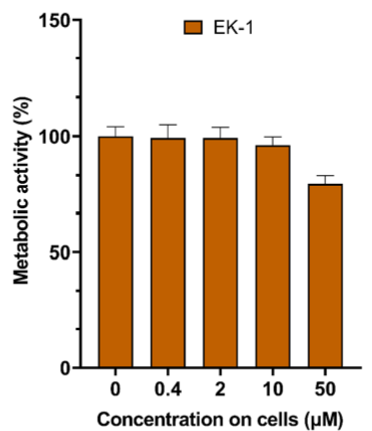

C

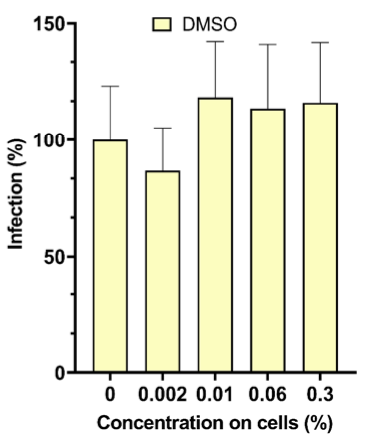

$\mathbf{F}$

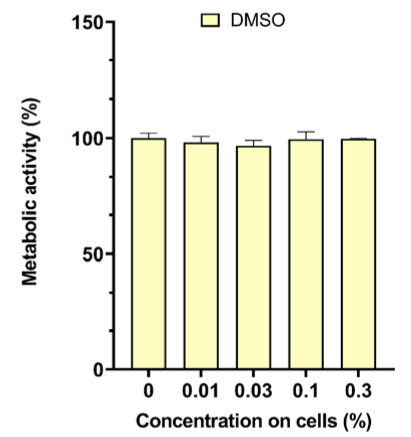

Figure 3. Effect of Cm-p5 peptides on SARS-CoV-2 pseudoparticle (PP) transduction. (A,C) Luciferase-encoding PP harboring the SARS-CoV-2 Spike protein were incubated with the peptides or the DMSO control for $1 \mathrm{~h}$ at $37^{\circ} \mathrm{C}$. Thereafter, the mixtures were inoculated on Caco2 cells, resulting in the indicated concentrations of the peptides on cells. The infection rates were determined $16 \mathrm{~h}$ post transduction by measuring the cell-associated luciferase activity. Shown above are the mean values derived from triplicate infections \pm SD (relative to controls containing no peptide, 100\%). (B) Caco2 cells containing the indicated concentrations of the SARS-CoV-2 inhibitory peptide EK1 were inoculated with SARS-CoV-2 PP, and the infection rates were determined as described under (A). (D-F) Metabolic activity of the Caco2 cells incubated with peptides for $48 \mathrm{~h}$. The metabolic activity of the cells was determined by an MTT assay (D,F) or CellTiter-Glo®Luminescent Cell Viability Assay (E). The effect of the Cm-p5 compound was measured in an independent experiment, but are shown in the same figure. Values shown are the mean values derived from triplicate measurements \pm SD (relative to controls containing no peptide, $100 \%$ ).

Next, we evaluated the possible antiviral effects of the peptides against ZIKV (Figure 4). For this, the virus was exposed to the peptides or PSVBS, a polyanionic polymer that was previously shown to inhibit the ZIKV infection [15]. Infectivity of virus/peptide or virus/PSVBS mixtures was then assessed by inoculating the Vero cells and the infection rates were determined two days later, by quantifying the amount of intracellular viral $\mathrm{E}$ protein by in-cell ELISA [16,17]. As shown in Figure 4A, none of the peptides reduced virus infection at concentrations up to $30 \mu \mathrm{g} / \mathrm{mL}$ during virion treatment. In contrast, PSVBS inhibited ZIKV infection in a concentration-dependent manner (Figure 4B) and DMSO had no significant effect on infection rate in the concentrations used (Figure 4C). At high concentrations $>300 \mu \mathrm{g} / \mathrm{mL}$, the three $\mathrm{Cm}$-p 5 derivatives showed some cytotoxicity to the Vero cells (Figure 4D), whereas, the reference inhibitor PSVBS (Figure 4E) or DMSO in the concentrations used (Figure 4F) showed significant toxicity at the highest concentration tested. 
A

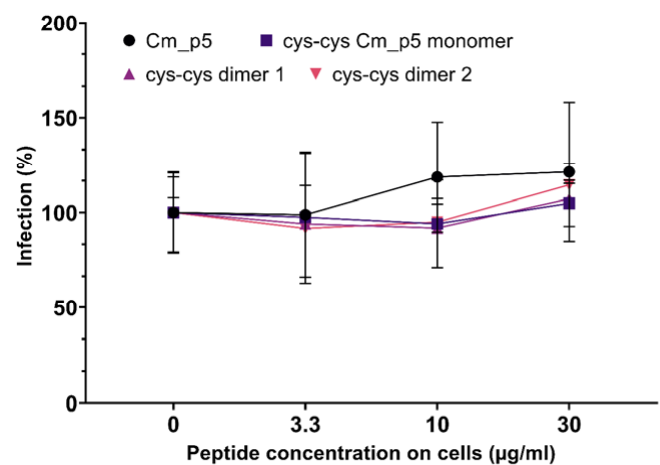

D

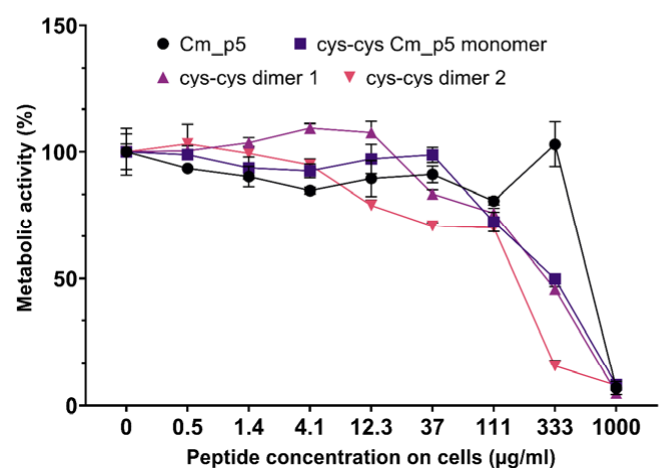

B

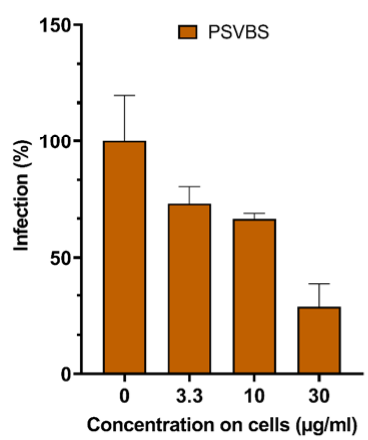

$\mathbf{E}$

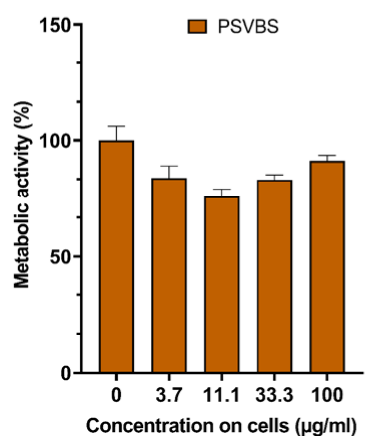

C

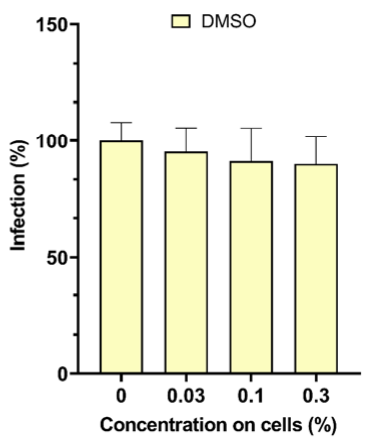

$\mathbf{F}$

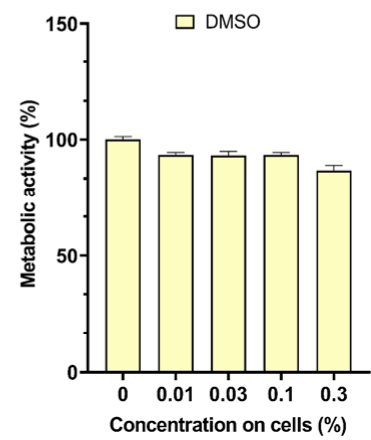

Figure 4. Effect of Cm-p5 and derivatives on ZIKV infection. (A-C) ZIKV was incubated for $1 \mathrm{~h}$ at $37^{\circ} \mathrm{C}$ with the peptides, DMSO control, or the polyanionic ZIKV inhibitor PSVBS. Thereafter, Vero cells were inoculated with the mixtures (resulting in the indicated concentration of the peptides on cells) and the viral infection rates were determined 2 days later, by quantifying the viral E protein by in-cell ELISA. Shown are mean values derived from triplicate infections \pm SD (relative to controls containing no peptide, 100\%). (D-F) Metabolic activity of Vero cells that were incubated for 2 days with the indicated concentrations of peptides and controls. Cell viability was determined by the MTT assay. The effect of the Cm-p5 compound was measured in an independent experiment, but are shown in the same figure. The values shown are the means derived from triplicate measurements \pm SD (relative to the controls containing no peptide, $100 \%$ ).

Finally, we analyzed whether $\mathrm{Cm}$-p5 and its derivatives might affect the HerpesSimplex Virus 2 (HSV-2) infection (Figure 5). For this, the virus was treated with peptides at concentrations up to $300 \mu \mathrm{g} / \mathrm{mL}$ for $2 \mathrm{~h}$ at $37^{\circ} \mathrm{C}$. Viral infectivity was determined by inoculating the ELVIS reporter cells that express $\beta$-galactosidase upon infection with HSV-1 or HSV-2 [12], the cells were incubated for $48 \mathrm{~h}$ with the peptides and the controls. As shown in Figure 5A, the parental Cm-p5 peptide did not affect the HSV-2 infection. Interestingly, the three derivatives resulted in a concentration-dependent inhibition of the HSV-2 infection with $\mathrm{IC}_{50}$ values of $\sim 144 \mu \mathrm{g} / \mathrm{mL}$ for the cys-cys monomer, $\sim 63 \mu \mathrm{g} / \mathrm{mL}$ for the dimer 1, and $275 \mu \mathrm{g} / \mathrm{mL}$ for dimer 2 (Figure $5 \mathrm{~A}$ ). Notably, at the highest concentration, dimer 1 almost completely inhibited the HSV-2 infection. PSVBS displayed potent antiviral activity and completely inhibited infection at $33 \mu \mathrm{g} / \mathrm{mL}$ (Figure 5B), whereas DMSO at the concentrations used showed no effect (Figure 5C). The $\mathrm{Cm}-\mathrm{p} 5$ compounds did not reduce metabolic activity of ELVIS cells at concentrations $<100 \mu \mathrm{g} / \mathrm{mL}$, but showed cytotoxicity at higher concentrations (Figure 5D). PSVBS and DMSO did not exert toxic effects at the concentrations tested (Figure 5E,F). 
A

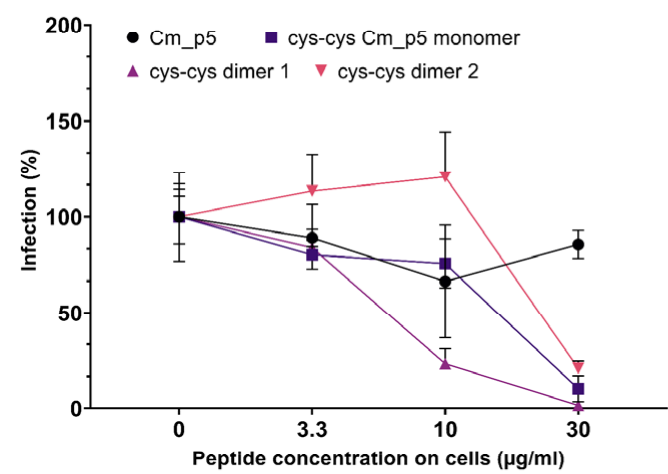

D

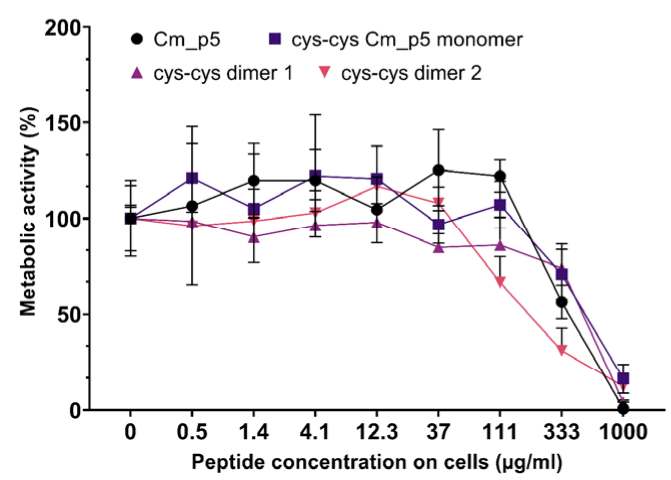

B

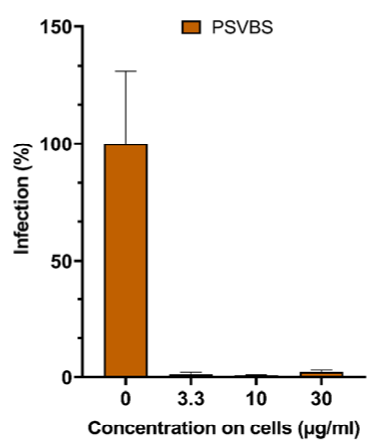

$\mathbf{E}$

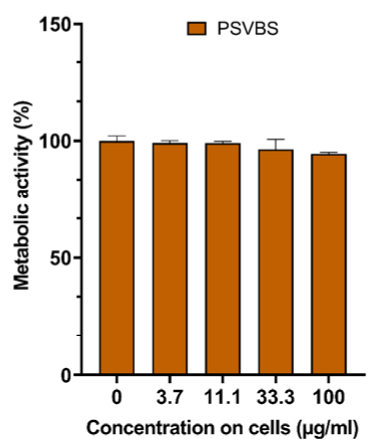

C

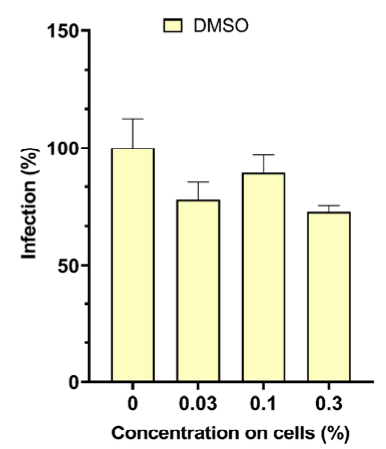

$\mathbf{F}$

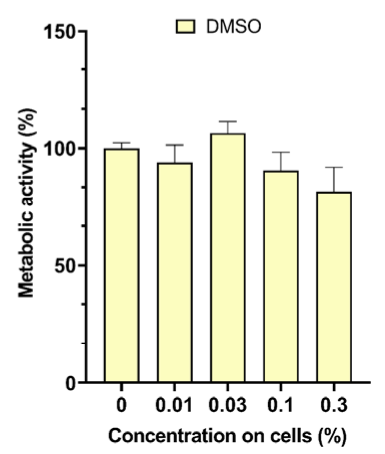

Figure 5. Cm-p5 derivatives inhibit the HSV-2 infection. (A-C) An HSV-2 stock was incubated with the peptides and controls for $30 \mathrm{~min}$ at $37^{\circ} \mathrm{C}$. Then, the ELVIS reporter cells were infected (resulting the indicated peptide concentrations on cells). The infection rates were determined one day later by measuring the cell-associated $\beta$-galactosidase activity in cellular lysates. Shown are the mean values derived from triplicate infections \pm SD (relative to controls containing no peptide, $100 \%$ ). (D-F) Metabolic activity of the ELVIS cells that were incubated for one day with the indicated concentrations of peptides and controls. Cell viability was determined by MTT assay. The values shown are means derived from triplicate measurements $\pm \mathrm{SD}$ (relative to controls containing no peptide, $100 \%$ ).

\section{Discussion}

In recent years, the emergence of a resistant microbial strain was observed against almost all classes of antimicrobials. In the current situation, novel antimicrobial agents are the only alternative to overcome this problem. One option are AMPs that were studied in great detail in the past decades and were approved for use [22]. However, the rational design of AMPs using natural occurring AMPs as a template is an alternative strategy with promising results. This approach overcomes various limitations of natural AMPs including reduced systemic toxicity and enhanced activity in blood/serum [23]. Considering these advantages, we evaluated the antimicrobial action of three derivatives of the antifungal peptide $\mathrm{Cm}$-p5 against multiresistant and problematic bacterial strains and some further major human pathogens.

We previously evaluated these $\mathrm{Cm}$-p5 derivatives against nonresistant bacterial and yeast strains; and they showed an improved antimicrobial action [3]. Therefore, we investigated the activity of these peptides against various multiresistant bacteria, including S. aureus MRSA, K. pneumoniae (ESBL), Acinetobacter baumanii, Pseudomonas aeruginosa and Enterococcus faecium VRE, all of which belong to the so-called ESKAPE pathogens, which are the cause of major problems in nosocomial infections worldwide [24]. K. pneumoniae (ESBL) is a multiresistant microorganism that is endemic in many communities and hospitals 
worldwide [25]. On the other hand, S. aureus MRSA is constitutively resistant to all $\beta$ lactam antibiotics and form part of the world health organization (WHO) "Global Priority List" of bacteria that represent the greatest threat to human health [26]. P. aeruginosa is another bacterium in this list, which causes severe infections with high morbidity and mortality in healthcare settings [27], but P. aeruginosa PA14 is a special strain with a high virulent potential [28]. Additionally to these multiresistant bacteria, we investigated the activity of the peptides against $S$. agalactiae, which is an important pathogen for pregnant women and children and causes severe septicemia and neonatal death. Moreover, it can cause diseases such as meningitis, septicemia, abscesses, infections in the urinary tract, and arthritis, particularly in immunocompromised adults [29,30].

The unmodified parent peptide $\mathrm{Cm}$-p5 did not exhibit any antibacterial activity, which we expected in accordance with previous results [31]. Different to $\mathrm{Cm}-\mathrm{p} 5$, its derivatives exhibited different degrees of antimicrobial activity against various bacterial species, including highly resistant strains like E. faecium VRE and K. pneumonia ESBL (Table 1). All derivatives showed antibacterial activity in agar diffusion assay at $1000 \mu \mathrm{g} / \mathrm{mL}$ against 6 of the 7 bacterial strains tested (Table 1). At concentrations of $20 \mu \mathrm{g} / \mathrm{mL}$, the dimer 1 and dimer 2 still inhibited 4 or 5 of the 7 bacterial strains tested, respectively. In the same assay, LL-37 showed a potent activity against 5 of the 6 bacterial strains tested at a concentration of $1 \mu \mathrm{g} / \mathrm{mL}$. The agar diffusion assay was influenced by a number of variables, including the diffusion of the antibiotic compound into the agar [32]. Some AMPs cannot spread very well in the agar, for this reason, we did an MIC determination using the broth dilution method (see Table 2). In this experiment, dimer 2 was the most active peptide, as demonstrated by an MIC value of $12.5 \mu \mathrm{g} / \mathrm{mL}$ against $L$. monocytogenes and a MIC value of $25 \mu \mathrm{g} / \mathrm{mL}$ against $A$. baumanii and E. faecium VRE. On the other hand, none of the Cm-p5 derivatives exhibited an antibacterial activity at $100 \mu \mathrm{g} / \mathrm{mL}$ against K. pneumoniae ESBL and S. agalactiae. Compared to the MIC values determined for LL-37 under similar conditions-depending on the bacterial strain - the resulting MIC values were within a range of $14-224 \mu \mathrm{g} / \mathrm{mL}$ [33]. Our results demonstrated that $\mathrm{Cm}-\mathrm{p} 5$ derivatives were moderately active against multiresistant bacterial strains and mainly against the Gram-negative ones.

Table 2. MIC determinations of CMP5 cys-cys monomer and dimer 1 and dimer 2. MIC determinations were performed in the Mueller-Hinton broth in accordance with CLSI guidelines, following overnight incubation at $37^{\circ} \mathrm{C}$. All tests were performed in triplicates.

\begin{tabular}{cccc}
\hline MIC Values & $\begin{array}{c}\text { AMP Monomer } \\
\text { (MIC) }\end{array}$ & $\begin{array}{c}\text { AMP Dimer 1 } \\
\text { (MIC) }\end{array}$ & $\begin{array}{c}\text { AMP Dimer 2 } \\
\text { (MIC) }\end{array}$ \\
\hline Streptococcus agalactiae & $>100 \mathrm{mg} / \mathrm{L}$ & $>100 \mathrm{mg} / \mathrm{L}$ & $>100 \mathrm{mg} / \mathrm{L}$ \\
\hline Listeria monocytogenes & $100 \mathrm{mg} / \mathrm{L}$ & $50 \mathrm{mg} / \mathrm{L}$ & $12.5 \mathrm{mg} / \mathrm{L}$ \\
\hline Pseudomonas aeruginosa & $>100 \mathrm{mg} / \mathrm{L}$ & $>100 \mathrm{mg} / \mathrm{L}$ & $>100 \mathrm{mg} / \mathrm{L}$ \\
\hline Klebsiella pneumoniae ESBL & $>100 \mathrm{mg} / \mathrm{L}$ & $>100 \mathrm{mg} / \mathrm{L}$ & $>100 \mathrm{mg} / \mathrm{L}$ \\
\hline Acinetobacter baumanii & $100 \mathrm{mg} / \mathrm{L}$ & $50 \mathrm{mg} / \mathrm{L}$ & $25 \mathrm{mg} / \mathrm{L}$ \\
\hline Enterococcus faecium VRE & $50 \mathrm{mg} / \mathrm{L}$ & $50 \mathrm{mg} / \mathrm{L}$ & $25 \mathrm{mg} / \mathrm{L}$ \\
\hline
\end{tabular}

Tuberculosis (TB) is a reemergent disease due to the appearance and spread of multidrug-resistant strains (MDR-TB) [34]. Traditionally the treatment of TB was based on four drugs-isoniazid, rifampicin, pyrazinamide, and thambutol, but currently exists as a strong necessity for new anti-tuberculosis candidates. In last decades, many studies established that several AMP exert activity against Mtb [35]. Some peptides like Nisin $\mathrm{S}$, a bio-engineered hinge derivative of Nisin A, have a potential effect over growth of $\mathrm{Mtb}$, when compared to Nisin A [36]. It was reported that human $\beta$-defensins have antimycobacterial action and their analogues, such as hBD-Pep4, even showed an increase activity [37]. 
Design of the peptide derivatives is a useful strategy to generate potential antimicrobial agents. In this study, we were able to show that the synthesis of the monomeric analogue and the two dimers of $\mathrm{Cm}$-p5 led to an increase in the activity against virulent extracellular $\mathrm{Mtb}$, as compared to the parental peptide. The effect adds up to a two-fold increase in activity, even at low concentrations $(30 \mu \mathrm{g} / \mathrm{mL})$.

For many viral pathogens, no approved drugs exist (SARS-CoV-2, ZIKV) or current treatment options are not optimal because of side effects, low efficacy, or development of resistance (HSV-2). In this context, we evaluated the antiviral action of $\mathrm{Cm}$-p5 derivatives against SARS-CoV-2, ZIKV, and HSV-2. All these viruses are enveloped, and could thus be targeted by peptides that act via interaction with the lipid membrane, regardless of the nucleic acid nature of the viral genome [38].

We did not observe antiviral effects of Cm-p5 and its derivatives against the ZIKV and SARS-CoV-2 pseudoparticles, at concentrations of up to $300 \mu \mathrm{g} / \mathrm{mL}$. However, the three optimized derivatives showed a concentration-dependent anti-HSV-2 effect. These data show that the $\mathrm{Cm}$-p5 derivatives do not exert a broad-antiviral activity but rather seem to inhibit a specific viral pathogen. Whether this was indeed the case, or whether the derivatives might also inhibit related viruses, such as HSV-1 or other herpesviruses, remains to be analyzed. It might also be possible that the $\mathrm{Cm}$-p 5 derivatives might not target the viral envelope bilayer but rather a HSV-2 glycoprotein that is essential for viral attachment or entry. The observed antiviral activity of the most potent derivative is in the median $\mu \mathrm{g} / \mathrm{mL}$ range, and thus is clearly too high for a systemic administration. However, it needs to be considered that HSV-2 is a sexually transmitted viral pathogen. Microbicides that aim to protect women form acquiring HSV-2 are applied topically onto the vagina mucosa, and creams or gels that contain $\mathrm{mg} / \mathrm{mL}$ concentrations of antivirally active peptides can be easily formulated. Our experiments confirmed that cyclization of Cm-p5 improved their antimicrobial activity, specially the antibacterial one. This strategy was used by other authors such as Gongora-Benitez and colleagues. This group reported that cyclization of peptides could enhance the pharmacological properties (potency, selectivity, stability, bioavailability, etc.) of their linear counterparts [39]. Although our peptides showed some promising antimicrobial and antiviral activity, compared to other AMPs, it is lower and a potential toxicity is clearly visible using concentrations $>100 \mu \mathrm{g} / \mathrm{mL}$ (Figure 3D, Figure 4D and Figure 5D), which is a major concern and limitation. We believe that our present results could lead to future research toward improvement of Cm-p5 potency and reduced toxicity of its derivatives.

\section{Conclusions}

We synthesized three Cysteine-containing derivatives of the snail-derived peptide $\mathrm{Cm}$-p5. The cyclic monomer, as well as a parallel and an antiparallel dimer of Cm-p5, showed an improved activity against the multiresistant strains of bacteria, including a virulent extracellular strain of Mycobacterium tuberculosis, and against HSV-2. Since the gap between effective concentrations and the start of toxic concentrations is quite narrow, further optimization of these sequences needs to be carried out.

Author Contributions: M.G.-G. performed bacterial testing and wrote parts of the manuscript. F.M.-V., E.D.P., H.G., and A.A.R.A. carried out peptide synthesis or purification and checked peptide quality by M.G. and chromatography. F.M.-V. is the author of Figure 1 (structures of the analogues), D.G.R. supervised peptide synthesis. M.G. tested peptides on mycobacteria and measured the cytotoxicity. L.R.O., R.G., C.C., F.K., F.Z., C.P.B., and J.A.M. carried out testing of peptides on different viral strains and the corresponding cytotoxicity of the peptides against the used human cells. A.Z. and J.M. supervised antiviral testing and data evaluation. H.R. and D.K. performed experiments on P. aeruginosa. F.R. supervised testing on P. aeruginosa and data evaluation. S.S. supervised testing on mycobacteria. B.S. supervised antibacterial testing using agarose diffusion assay. O.L.F. supervised the study and helped to write the manuscript. L.S. and A.J.O.-G. designed the study and wrote parts of the manuscript. All authors have read and agreed to the published version of the manuscript. 
Funding: This work was funded in part by the German Federal Ministry of Education and Research (BMBF) project (DLR CUB 17WTZ-014/01DN18009), the German Research Society (DFG) project CRC1279 (Exploiting the Human Peptidome for Novel Antimicrobial and Anticancer Agents), CAPES Funding Sources, Brazil, and Havana University, Cuba. This project received funding from the European Union's Horizon 2020 research and innovation programme under grant agreement No. 101003555 (Fight-nCoV) to J.M. J.A.M. is indebted to the Baden-Württemberg Stiftung for the financial support of this research project by the Eliteprogramme for Postdocs. F.Z., R.G., and L.R.O. are part of the International Graduate School in Molecular Medicine Ulm, which also provides a scholarship to R.G. Parts of the project were funded by the Alexander Humboldt Foundation (1160914-COL-IP) to L.S.

Institutional Review Board Statement: Not applicable.

Informed Consent Statement: Not applicable.

Data Availability Statement: Data is contained within the article.

Acknowledgments: The authors thank the Laboratory of Synthetic Peptides, Center for Genetic Engineering and Biotechnology, La Habana, Cuba, and Laboratory of Pharmaceutical Biotechnology, Department of Drugs and Medicines, School of Pharmaceutical Sciences, UNESP, Araraquara, Brazil.

Conflicts of Interest: The authors declare no conflict of interest.

\section{References}

1. López-Abarrategui, C.; McBeth, M.; Mandal Santi, J.; Sun Zhenyu, G.; Heffron, A.; Alba-Menéndez, L.; Migliolo, O.; Reyes-Acosta, M.; García-Villarino, D.O.; Nolasco, R.; et al. Cm-p5: An antifungal hydrophilic peptide derived from the coastal mollusk Cenchritis muricatus (Gastropoda: Littorinidae). FASEB J. 2015, 29, 3315-3325. [CrossRef]

2. González-García, M.; Valdés, M.; Freitas, C.G.; Alba Menéndez, A.; López-Abarrategui, C.; San Juan Galán, J.; Campos Diaz, S.; Luiz Franco, O.; Otero-González, A. In vitro complementary biological activity of the antifungal peptide Cm-p5 and in silico prediction of its functional regions. Rev. Cuba. Med. Trop. 2017, 69, 1-15.

3. Vicente, F.E.M.; González-Garcia, M.; Diaz Pico, E.; Moreno-Castillo, E.; Garay, H.E.; Rosi, P.E.; Jimenez, A.M.; Campos-Delgado, J.A.; Rivera, D.G.; Chinea, G.; et al. Design of a Helical-Stabilized, Cyclic, and Nontoxic Analogue of the Peptide Cm-p5 with Improved Antifungal Activity. ACS Omega 2019, 4, 19081-19095. [CrossRef] [PubMed]

4. Kumar, P.; Kizhakkedathu, J.; Straus, S. Antimicrobial Peptides: Diversity, Mechanism of Action and Strategies to Improve the Activity and Biocompatibility In Vivo. Biomolecules 2018, 8, 4. [CrossRef]

5. Cusimano, M.; Spinello, A.; Barone, G.; Schillaci, D.; Cascioferro, S.; Magistrato, A.; Parrino, B.; Arizza, V.; Vitale, M. A Synthetic Derivative of Antimicrobial Peptide Holothuroidin 2 from Mediterranean Sea Cucumber (Holothuria tubulosa) in the Control of Listeria monocytogenes. Mar. Drugs 2019, 17, 159. [CrossRef]

6. Hancock, R.E.; Sahl, H.G. Antimicrobial and host-defense peptides as new anti-infective therapeutic strategies. Nat. Biotechnol. 2006, 24, 1551-1558. [CrossRef] [PubMed]

7. Lai, Y.; Gallo, R.L. AMPed up immunity: How antimicrobial peptides have multiple roles in immune defense. Trends Immunol. 2009, 30, 131-141. [CrossRef]

8. Otero-González, A.J.; Magalhaes, B.S.; García-Villarino, M.C.; López-Abarrategui, C.; Sousa, D.A.; Dias, S.C. Antimicrobial peptides from marine invertebrates as a new frontier for microbial infection control. FASEB J. 2010, 24, 1320-1334. [CrossRef]

9. Steinstraesser, L.; Kraneburg, U.; Jacobsen, F.; Al-Benna, S. Host defense peptides and their antimicrobial-immunomodulatory duality. Immunobiology 2011, 216, 322-333. [CrossRef]

10. Shurko, J.F.; Galega, R.S.; Li, C.; Lee, G.C. Evaluation of LL-37 antimicrobial peptide derivatives alone and in combination with vancomycin against $S$. aureus. J Antibiot. 2018, 71, 971-974. [CrossRef]

11. Graham, F.L.; Smiley, J.; Russell, W.C.; Nairn, R. Characteristics of a human cell line transformed by DNA from human adenovirus type 5. J. Gen. Virol. 1977, 36, 59-74. [CrossRef]

12. Proffitt, M.R.; Schindler, S.A. Rapid detection of HSV with an enzyme linked virus inducible system (ELVIS) employing a genetically modified cell line. Clin. Diagn. Virol. 1995, 4, 175-182. [CrossRef]

13. CLSI. Instruction for susceptibility assay for bacteria. In Methods for Dilution Antimicrobial Susceptibility Tests for Bacteria That Grow Aerobically; Clinical and Laboratory Standards Institute: Wayne, PA, USA, 2018.

14. Dick, G.W.; Kitchen, S.F.; Haddow, A.J. Zika virus. I. Isolations and serological specificity. Trans. R. Soc. Trop. Med. Hyg. 1952, 46, 509-520. [CrossRef]

15. Schandock, F.; Riber, C.F.; Röcker, A. Macromolecular Antiviral Agents against Zika, Ebola, SARS, and Other Pathogenic Viruses. Adv. Healthc. Mater. 2017, 6, 1700748. [CrossRef]

16. Aubry, M.; Richard, V.; Green, J.; Broult, J.; Musso, D. Inactivation of Zika virus in plasma with amotosalen and ultraviolet A illumination. Transfusion 2016, 56, 33-40. [CrossRef] 
17. Müller, J.A.; Harms, M.; Krüger, F. Semen inhibits Zika virus infection of cells and tissues from the anogenital region. Nat. Commun. 2018, 9, 2207. [CrossRef] [PubMed]

18. Hoffmann, M.; Kleine-Weber, H.; Schroeder, S. SARS-CoV-2 Cell Entry Depends on ACE2 and TMPRSS2 and Is Blocked by a Clinically Proven Protease Inhibitor. Cell 2020, 181, 271-280.e8. [CrossRef]

19. Berger Rentsch, M.; Zimmer, G. A vesicular stomatitis virus replicon-based bioassay for the rapid and sensitive determination of multi-species type I interferon. PLoS ONE 2011, 6, e25858. [CrossRef] [PubMed]

20. Xia, S.; Zhu, Y.; Liu, M. Fusion mechanism of 2019-nCoV and fusion inhibitors targeting HR1 domain in spike protein. Cell. Mol. Immunol. 2020, 17, 1-3. [CrossRef] [PubMed]

21. Xia, S.; Liu, M.; Wang, C. Inhibition of SARS-CoV-2 (previously 2019-nCoV) infection by a highly potent pan-coronavirus fusion inhibitor targeting its spike protein that harbors a high capacity to mediate membrane fusion. Cell Res. 2020, 30, 343-355. [CrossRef]

22. Baindara, P.; Ghosh, A.K.; Mandal, S.M. Coevolution of Resistance against Antimicrobial Peptides. Microb. Drug Resist. 2020, 26, 880-899. [CrossRef] [PubMed]

23. Pandit, G.; Biswas, K.; Ghosh, S.; Debnath, S.; Bidkar, A.P.; Satpati, P.; Bhunia, A.; Chatterjee, S. Rationally designed antimicrobial peptides: Insight into the mechanism of eleven residue peptides against microbial infections. Biomembranes 2020, $1862,183177$. [CrossRef] [PubMed]

24. Mulani, M.S.; Kamble, E.E.; Kumkar, S.N.; Tawre, M.S.; Pardesi, K.R. Emerging Strategies to Combat ESKAPE Pathogens in the Era of Antimicrobial Resistance: A Review. Front. Microbiol. 2019, 10, 539. [CrossRef]

25. Girometti, N.; Lewis, R.E.; Giannella, M.; Ambretti, S.; Bartoletti, M.; Tedeschi, S.; Tumietto, F.; Cristini, F.; Trapani, F.; Gaibani, P.; et al. Klebsiella pneumoniae Bloodstream Infection: Epidemiology and Impact of Inappropriate Empirical Therapy. Medicine 2014, 93, 298-308. [CrossRef] [PubMed]

26. Meade, E.; Slattery, M.A.; Garvey, M. Bacteriocins, Potent Antimicrobial Peptides and the Fight against Multi Drug Resistant Species: Resistance Is utile? Antibiotics 2020, 9, 32. [CrossRef] [PubMed]

27. Geitani, R.; Moubareck, C.A.; Touqui, L.; Sarkis, D.K. Cationic antimicrobial peptides: Alternatives and/or adjuvants to antibiotics active against methicillin-resistant Staphylococcus aureus and multidrug-resistant Pseudomonas aeruginosa. BMC Microbiol. 2019, 19, 54. [CrossRef]

28. Mikkelsen, H.; McMullan, R.; Filloux, A. The Pseudomonas aeruginosa reference strain PA14 displays increased virulence due to a mutation in ladS. PLoS ONE 2011, 6, e29113. [CrossRef]

29. Bolukaoto, J.Y.; Monyama, C.M.; Chukwu, M.O.; Lekala, S.M.; Nchabeleng, M.; Maloba, M.R.B.; Mavenyengwa, R.T.; Lebelo, S.L.; Monokoane, S.T.; Tshepuwane, C.; et al. Antibiotic resistance of Streptococcus agalactiae isolated from pregnant women in Garankuwa, South Africa. BMC Res. Notes 2015, 8, 364. [CrossRef] [PubMed]

30. Jaramillo-Jaramillo, A.S.; Cobo-Ángel, C.G.; Moreno-Tolosa, Y.; Ceballos-Márquez, A. Resistencia antimicrobiana de Streptococcus agalactiae de origen humano y bovino. Rev. CES Med. Zootec. 2018, 13, 62-79. [CrossRef]

31. López-Abarrategui, C.; Alba, A.; Silva, O.; Reyes-Acosta, I.M.; Vasconcelos, J.T.A.; Olivera, L.; Migliolo, M.P.; Costa, C.R.; Costa, M.R.R.; Silva, H.E.; et al. Functional characterization of a synthetic hydrophilic antifungal peptide dericed from the marine snail Cenchritis muricatus. Biochimie 2012, 94, 968-974. [CrossRef]

32. Balouiri, M.; Sadiki, M.; Ibnsouda, S.K. Methods for in vitro evaluating antimicrobial activity: A review. J. Pharm. Anal. 2016, 6, 71-79. [CrossRef]

33. Leszczynska, K.; Namiot, D.; Byfield, F.J.; Cruz, K.; Zendzian-Piotrowska, M.; Fein, D.E.; Savage, P.B.; Diamond, S.; McCulloch, C.A.; Janmey, P.A.; et al. Antibacterial activity of the human host defence peptide LL-37 and selected synthetic cationic lipids against bacteria associated with oral and upper respiratory tract infections. J. Antimicrob. Chemother. 2013, 68, 610-618. [CrossRef] [PubMed]

34. Borrero, R.; Álvarez, N.; Reyes, F.; Sarmiento, M.E.; Acosta, A. Mycobacterium tuberculosis: Factores de virulencia. Vacci Monit. 2011, 20, 34-38.

35. AlMatar, M.; Makky, E.A.; Yakici, G.; Var, I.; Kayar, B.; Koksal, F. Antimicrobial peptides as an alternative to anti-tuberculosis drugs. Pharmacol. Res. 2017, 128, 288-305. [CrossRef]

36. Carroll, J.; Field, D.; O'Connor, P.M.; Cotter, P.D.; Coffey, A.; Hill, C. Gene encoded antimicrobial peptides, a template for the design of novel anti-mycobacterial drugs. Bioeng. Bugs 2010, 1, 408-412. [CrossRef]

37. Corrales-Garcia, L.; Ortiz, E.; Castañeda-Delgado, J.; Rivas-Santiago, B.; Corzo, G. Bacterial expression and antibiotic activities of recombinant variants of human beta-defensins on pathogenic bacteria and M. tuberulosis. Protein Expr. Purif. 2013, 89, 33-43. [CrossRef] [PubMed]

38. Sala, A.; Ardizzoni, A.; Ciociola, T.; Magliani, W.; Conti, S.; Blasi, E.; Cermelli, C. Antiviral Activity of Synthetic Peptides Derived from Physiological Proteins. Intervirology 2018, 61, 166-173. [CrossRef] [PubMed]

39. Góngora-Benítez, M.; Tulla-Puche, J.; Albericio, F. Multifaceted Roles of Disulfide Bonds. Peptides as Therapeutics. Chem. Rev. 2014, 114, 901-926. [CrossRef] 